\title{
Towards African Renaissance: A Linguistic Study of Ayi Kwei Armah's Two Thousand Seasons
}

\author{
G. I. Omo-Ojugo
}

\section{ABSTRACT}

This study focuses on the exploration of Africa concept of a dream world a continent marching towards a rebirth, towards that utopia that Joseph Edoki wrote about in The Upward Path (Edoki, 2008). This Africa concept of rebirth does not believe in jumping the gun to get to the utopia, but rather beams the searchlight on the opportunities, challenges and prospects that are littered all along the trajectory of the journey to that utopia Africans look forward to. For long, Africa as a continent was captured in slavery and this took its toll on the people as they developed inferiority complex, low self-esteem, no love loss, among others. Thus, at the expiration of colonialism, so much damage had been done. Ayi Kwei Armah's Two Thousand Seasons (Armah, 1979) warns against a repeat of the cause of the desolation in the first place, and then illustrates that the only escape route is to return to "The Way" which Africans have lost. Thus, the text is about a people depressed, a people neglected, and a people striving to recover their identity even from the hands of their own people. This paper is a linguistic study of Armah's Two Thousand Seasons set to investigate the novelist's level of success in the employment of the creative linguistic features aimed at driving home his message about African struggle for survival on the one hand, and highlighting the difficulties encountered in the course of pursuing rebirth on the other hand. Halliday's Systemic Functional Approach has been adopted in this work.

Keywords: Destruction, Purposes, Rebirth, the Way

Published Online: January 21, 2022

ISSN: $2736-5522$

DOI: $10.24018 /$ ejsocial.2022.2.1.194

G. I. Omo-Ojugo*

Ambrose Alli University Ekpoma, EdoState, Nigeria.

(e-mail: omo.ojugo ${ }^{@}$ gmail.com)

\section{INTRODUCTION}

Geographically, Africa is the World's second-largest continent after Asia. The continent is bounded on the west by the Atlantic Ocean, on the north by the Mediterranean Sea, on the east by the Red Sea and the Indian Ocean, and on the south by the mingling waters of the Atlantic and Indian Oceans. There are a number of islands associated with the continent, the example of Madagascar and other smaller ones. Africa stretches for a distance of about 8000km north to south, from Bizerte in Tunis down to Cape Agulhas in South Africa along longitude 20oE. (Eze, 2008). Thus, the African continent is the most tropical of all the continents.

Africa is a term used collectively to refer to all the indigenous ethnic groups of the African continent. This means that an African is exclusively a person from the indigenous ethnic groups found on the continent of Africa. An African is one who traces his/her ancestry to these groups in the African race (Diaspora). Chester Higgins Jr. (2010) notes that there are at least 3,000 distinct ethnic groups in the African landscape all with specific adaptations to living in the African landscape. Higgins (2010) affirms that Africans were Africans because they were born Africans, but because Africa is born in them.

Higgins notes that Africa has approximately 58 countries. It occupies a wide dynamic latitude, has desert, forest, snow, temperate climate, tropics, sub-tropics, lakes, the longest river, lowest point on Earth, mountain ranges; and that the indigenous African continent is made up of blessed people with striking distinctive beauty - dark skin, hair texture, rich food, rich cultural values and religious practices.

1) The word "Renaissance" is a French word for "rebirth." Renaissance is a period of an intense interest in learning about classical antiquity. Jessie Szalay (2016) opines that the term renaissance typically refers to a period in European history, approximately between 1400 and 1600 and that Renaissance bridged the periods of the Middle Ages and modern history. Renaissance thinker considered the Middle Ages to have been a period of cultural decline. They revitalized their culture through reemphasizing classical texts and philosophies.

However, the general understanding of the African Renaissance is of a nostalgic movement, calling for 
a return to one's home. Africa has gone through several phases: slavery, colonialism, independence and neo-colonialism in the hands of those who came cunningly as beggars but turned vipers after being given sustenance. These Arabs from across the desert and the white Europeans from across the Atlantic Ocean abused the hospitality Africans showed to them. This deceptive attitude can be likened to Olaniyi Oyedele (2020), "Important Security Admonition: Remember Hudaybiyyah." This statement was a response from Yasser Arafat, the PLO (Palestine Liberation Organisation) Chief in 1993, when he was heavily criticized by the Arab World for signing the Oslo Peace Agreement with its mortal enemy, Israel. What Arafat referred to happen several centuries before it was called the Treaty of Hudaybiyyah, from which Olaniyi Oyedele adopted his write-up, www.arabnews.com. This was supposed to be a 10-year treaty between the Prophet Muhammed and citizens of Mecca during which there was supposed to be a period of cessation of hostility and peace between the two warring parties. However, to portray the deception inherent in some unpatriotic leaders, the paper states that Prophet Muhammed used the transition period immediately following the signing of the treaty and cessation of hostilities, to gather and strengthen his army, reposition his troops, within two years of the ten - year treaty, thereby breaking the provisions of the treaty. Meanwhile, the paper opines that the citizens of Mecca, who were unsuspecting, were subdued.

Oyedele notes in war, all options are on the table and that deceit is the primary option often deployed to incapacitate the enemy. The Arabs, who came from across the desert, pleading to be given sustenance, deployed deceptive strategy to overrun the continent after studying it.

Again, as Carl Von Clausewitz (2012) once said in the same write-up but with the heading "Politics is war by other means," relayed how the Fulani take politics as war and have always abided by this principle and often used the art of deception in its political machinations. By way of comparison, this practice is replicated in Nigeria, where the incumbent President is a Fulani. The government of Nigeria has been accused over and over again of Fulani ethnic bias, favouritism in political appointments and offices and in the military. Those occupying key positions in the government are mainly from the Fulani nation, where the president comes from. This has resulted in an overwhelming dominance of the key positions of military and para-military and other para military agencies by the Fulani stock. Meanwhile, during his campaign, he had promised to be president for all the people of Nigeria. This ethnic bias in favour of the Fulani ethnic nationality has been of great delight to the Fulani and to the Northern Elders and Emirs in Nigeria. This scenario has put the Fulani herdsmen at an advantage. They have become emboldened in their quest to take over and occupy the lands belonging to indigenous people of Benue, Plateau and other parts of Nigeria. This is because all arrest made have been of no consequence as orders from higher authorities demand immediate release of the rampaging and ravaging herdsmen. The tactic approval of this dangerous trend has led to the infiltration of Fulani terrorists and Jihadists from other parts of Africa and beyond. The powers that have not seen anything seriously wrong in this adventure of these people who have killed, raped and maimed because of the "Fulanisation" and "Islamisation" agenda. The terrorists, bandits and kidnappers that have come from outside the country have joined forces with the criminal elements in the country to turn the heat of terror on the people of the north, whether they are Emirs or people holding government position.

Von Clausewitz (2012) has observed how deceit is always at the heart of its politics and governance. He relayed in the paper, how during the first republic in Nigeria, Chief Obafemi Awolowo, who was the premier of western region, had heard that a state of emergency was to be declared in the Western Region, so he sought the audience of the Prime Minister, Tafawa Belewa during the legislative session.

At the meeting, Awo told the Prime Minister about the rumors he was hearing that a state of emergency was to be declared in the west. Balewa reassured Awo that there was nothing of such and that even if such was to be contemplated it would have to be discussed and debated on the floor of the House. Reassured, Awolowo went home believing in the Honorable Prime Minister's words. However, contrary to the assurance Balewa had given to Awolowo, a state of emergency was declared that same midnight. Almost in the same manner, the current insecurity scenario in Nigeria vividly portrays the cunning and deceptive nature of unpatriotic politicians, who have not been able to secure the country. Nigeria which is supposed to be a secular state, is governed mainly by Moslems, who tacitly approve the Islamization agenda of the rampaging herdsmen and their cohorts.

Thus, Africa has gone through several phases, which have inflicted on her loss of dignity, political and economic domination, distorted African history, denial of African culture and the formation of stereotypical hardship, injustice and a sense of inferiority complex Zahra, (2008). These experiences have more or less imprisoned Africans. Consequently, this work will be examined along the following themes: African hospitality, European incursion, Exploitation by European invaders, Africans enslaved, tortured, and brutalised, and Reprisal by Africans. 


\section{THEORETICAL APPROACH}

Among the several theoretical approaches to the study of language, there are two competing linguistic ones often considered - Neo-Firthian Systemic Functional Approach propounded by M.A.K. Halliday and the Transformational Generative Grammar propounded by Noam Chomsky. Both models have a common goal of accounting for how language works which is in recognition of constituent structure and deep structure realized differently by the two models. In TGG Model, the deep structure is realized through transformation while Halliday's Systemic Functional Theory emphasizes sentence relation beyond the surface level. In this study, the Neo-Firthian Systemic Functional Approach propounded by M.A.K. Halliday is adopted because it is text centered and sensitive to the functions language performs in a text.

As has been mentioned earlier, this work is a linguistic study of Armah's Two Thousand Seasons. Linguistics, according to Hartmann and Stork (1972), is the field of study the subject of which is language. Linguists study language as man's ability to communicate, as individual expression, as the common heritage of a speech community... Thus, Armah in Two Thousand Seasons employs the use of language to advance the course of African liberation. The focus in this study is on the syntactic level of language.

Syntax, according to Abrams and Harpham (2005), is "the study of the way that sequences of words are ordered into phrases, clauses, and sentences... The editors of Encyclopaedia Britannica aver that the study of syntax include the investigation of relations among sentences that are similar, Linguistics: Syntax www.britannica.com. This similarity is referred to as syntactic parallelism or lexical parallelism.

\section{OBJeCTIVES OF THE STUdY}

The objectives of this study are to:

1. identify and analyse how Armah, through employment of grammatical features portrays the degree of ordeal Africans went through in their struggle to attain liberation in Two Thousand Seasons;

2. syntactically determine the level of Armah's success in communicating this message of oppression;

3. interrogate and explain the exploitative nature of man; and

4. ascertain that Africans are indeed hospitable group of people.

\section{A. African Hospitality}

Africans are hospitable people whose generosity Anoa the priestess in the text of our study warns them against. Anoa had repeatedly admonished Africans to "Turn from this generosity of fools," and that "the giving that split from receiving is no generosity but hatred of the giving self, a preparation for the self's destruction." She warns that Africans should "Return to the way, the way of reciprocity" (p. 25).

Anoa, the priestess, had prophesied seasons of hardship to the African community because of their generosity. She told them of a period they will lose their way and encounter something called slavery. "The way" referred to here is the spiritual way of life the community follows. "The way" is a way that aims at "preserving knowledge of who they are, knowledge of the best way they found to relate each to each, each to all, ourselves to peoples, all to our surroundings" (p. 61). The way is associated with healing and recreation. "The way" exhibits the glorious qualities of a far-distant past: the pre-colonial period of African history which Nwahunanya (2007) talks about in Literary Criticism, Critical Theory and Post-Colonial African Literature. Armah, in reflecting this great value of African hospitality, employs features of parallelism as captured in the extract below:

1. Our way is reciprocity. The way is wholeness. Our way know no oppression. The way destroys oppression. Our way is hospitable to guests. The way repels destroyers. Our way produces before it consumes. The way produces far more than it consumes. Our way creates. The way destroys only destruction (p. 62)

\begin{tabular}{|c|c|c|}
\hline$\overline{\mathrm{SS}}$ & 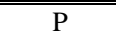 & Compliment \\
\hline Our way & $\begin{array}{c}\text { Is } \\
\text { Knows }\end{array}$ & $\begin{array}{l}\text { Reciprocity } \\
\text { Wholeness }\end{array}$ \\
\hline The way & Destroys & $\begin{array}{c}\text { no oppression } \\
\text { oppression }\end{array}$ \\
\hline Our way & Is & hospitable to guests \\
\hline The way & Repels & Destroyers \\
\hline Our way & $\begin{array}{c}\text { Produces } \\
\text { creates. } \\
\text { destroy }\end{array}$ & $\begin{array}{c}\text { before it consumes } \\
\text { only destruction. }\end{array}$ \\
\hline
\end{tabular}

Parallelism is the use of pattern repetition in a literary text for a particular stylistic effect (Yankson, 1987). Egenschmiler and Biggs (2001) note (that) elements in a sentence that have the same function or express similar ideas should be grammatically parallel, or grammatically matched as in the table above. 
They note that parallelism is used effectively as a rhetorical device throughout literature and in speeches, advertising copy and popular songs (Egenschmiler \& Biggs, 2001). The followings are their examples:

Reading is to the mind what exercise is to the body. (Parallel Structure).

He liked their courage, stamina, and style. (Parallel).

He liked their courage, their stamina, and their style. (Parallel).

The schools in the suburbs are better than the schools in the city. (Parallel- schools in the suburbs are being contrasted with schools in the inner city). Armah employs both syntactic parallelism and lexical parallelism to advance the course of African liberation.

Armah rhetorically employs the following lexical items and phrases - "reciprocity," "wholeness," "no oppression," "hospitable to guests," "repels destroyers," "produces before it consumes," and "destroy only destruction" to emphasize and to constantly remind his readers of the ideology associated with their way of life. The "way" is very important to them because "it aims at preserving knowledge of who they are, knowledge of the best way we have found to relate each to each, each to all, ourselves to other people, all to our surroundings" (p. 61).

The use of the personal pronoun "our" in the parallel structures signals the author who is involved in the advocacy for a team spirit to preserve all that belong to Africans. This concept of caring and protecting is amplified in the following sentence thus: "If our individual lives have a worthwhile aim, that aim should be a purpose inseparable from the way" (p. 61). The use of the structures, indicates Armah's clarion call on Africans to embrace unity, live in beautiful relationship, and hospitality among one another. All the structures in the extract above portray the ideology the people canvass concerning "the way". An ideology in line with God's commandment, to love Him and our neighbours as ourselves.

2. Their news was also of relationships of a beauty still to be realized, of paths still to be found. Their news was of the way, the forgotten and the future (p. 7).

TABlE II: PARAlytic StRUCTURES PORTRAying AFRICANS AS A PEOPLE WITH Vision AND MisSiON

\begin{tabular}{ccc}
\hline \hline S & $\mathrm{P}$ & Complement \\
\hline Their news & was & $\begin{array}{c}\text { also of relationships of a } \\
\text { beauty still to be realised, of } \\
\text { paths still to be found. } \\
\text { of the way, the forgotten } \\
\text { and the future. }\end{array}$ \\
\hline \hline
\end{tabular}

In the above table, Armah rhetorically expresses how people of the way have always moved towards a rebirth of their ideology which is reciprocity. Thus, the people were always on motion avoiding trouble and compromise. "Generation after generation, growing groups journeyed a day, three days from our outer reaches looking not for escape but for greater space in open land" (pp. 6-7). Armah notes that there was a group among them who didn't engage in physical traveling over land and water but engaged in psychological migration. This group documented nine past experiences. They had records of communities and relations and of genealogies, which had the capacity to take the people down the memory lane. They kept records of their roots. This group did not only document their past but also had record of what they intended to achieve - "their news was also of relationships of a beauty still to be realized," "of paths still to be found" "Their news was of the way, the forgotten and the future way" (p.7). The parallel structures above present the people of the way as a focused, foresighted, hardworking, and accommodating group of people.

\section{B. European Incursion and Exploitation}

The novel paints a picture of African invasion by the Arab predators and white European destroyers from across the desert and across the sea respectively. The plunderers who disguised as visitors turned around to disorganize the cultural milieu of the people. They used their religion to sway them. Through the use of lexical repetition "death" and "death," Armah highlights the word as a meaning inherent to the theme of the work. Armah, in extract 3 below, exposes the predators' cunning invasion in Africa.

3. Killers who from the desert brought us in the aftermath of Anoa's prophecy a choice of death: death of our spirit...The suspicious among us had pronounced fears incomprehensible to our spirit then, words generosity failed to understand. "These are makers of carrion," the wary ones said, "do not shelter them. See their eyes, their noses. Such are the beaks of all the desert's predatory birds" (p. 3). 
European Journal of Humanities and Social Sciences www.ej-social.org

TABLE III: REPETITION OF THE NOUN “DEATH” EMPHASIZES THE DANGER OF GIVING AND NOT RECEIVING

\begin{tabular}{cccc}
\hline S & P & O & Complement \\
$\begin{array}{c}\text { Killers who from } \\
\text { the desert }\end{array}$ & brought & Us & $\begin{array}{c}\text { in the aftermath } \\
\text { of Anoa's } \\
\text { prophecy a choice } \\
\text { of death: death of }\end{array}$ \\
\hline \hline
\end{tabular}

In the above extract, there is the repetition of the lexical word "death." Armah uses this pattern repetition to emphasize Anoa's warning against the people's openness, and how they would become enslaved because of their generosity. Anoa had prophesied the calamity that awaits them because of their continuous giving without receiving. This was the period when all the black people belonged to one vast African nation with its own genuine pure system of values or way of life which the novelist consistently refers to as "the way" or "our way". The main characteristic of this authentic African way is what Armah refers to as reciprocity, which is the principle of mutual giving and receiving, and because giving and receiving are intertwined, they constitute the principle of life, death ensues when the two are separated. The "way" is therefore, a way of life as opposed to the destroyers' way of death.

When these killers came from the desert, the suspicious among them expressed their fear and called them "makers of carrion." The wary ones among them actually said the migrants should not be accommodated and given shelter, alluding to them as desert's predatory birds in their "eyes and in their "noses." This meant that the strangers were like vultures who could prey on them. The irony here is that these strangers who came as beggars turned "green snakes" after feeding. They enslaved their host and turned them into playthings.

4. The white destroyers asked for land. The people told them land was not a thing to be possessed... If they wanted food, they could farm. If they wanted shelter they would always be welcome as guests. But as to owing land that was a request even babies would laugh at... The white destroyers went back silent to their ship. At night they brought it closer to Enchi and from it sent hot balls of iron flying through the air to destroy their hosts (p. 120).

Armah employs the use of indicative mood to stimulate and sensitize the reading African audience of the disaster caused by European imperialists in the 19th century. Armah reveals that the imperialists came specifically to Africa on economic basis. When these colonisers arrived Africa, they were treated charitably because "the way" prescribed that strangers should be given sustenance. Meanwhile, their motive was "to set up factory, a hunting station and church to mine the hills of Anoa for gold". When they discovered that Africans were aware of their ploy, they knew it would take a fight to achieve. The use of the adjectival phrase "white destroyer" reveals that Africans were right from the beginning suspicious of the European mission. Therefore, when they made their request for land, the response was a subtle "no."

5. In our generosity, they found their denied sustenance. A ruinous openness we had, for those who came as beggars turned snakes after feeding (p. 3).

In extract 5, Armah recants how Africans' generosity and hospitality make them prey in the hands of strangers. He relays how Africans received the first imperialists from the desert. These men came cunningly as beggars. As a result of their principle of reciprocity, which prescribed that strangers be given sustenance, the strangers were treated hospitably. These strangers came with an agenda to dispossess and subjugate them. After they have been given sustenance, they began to oppress their hosts. The strangers are credited with the attribute of a "snake". "Snakes" in this context connotes danger as portrayed in the componential analysis below:

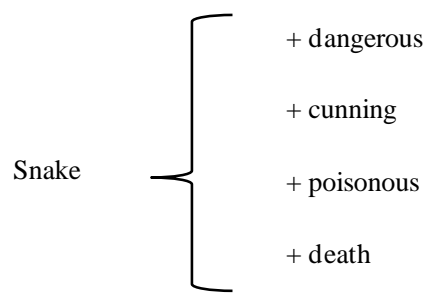

Fig.1. Comparative deceptive nature of the snake and strangers from across the desert

The crafty nature of the "snake" is revealed in the book of Genesis 3:1-5 (Zondervan, 1999). This was when it deceived Eve to eat of the tree which God commanded them not to. The crafty nature of the snake has become a cliché, "as cunning as the serpent".

Despite the several abuses, humiliation and slavery Africans suffered as a result of Africans' principle of reciprocity, Africans will continue to strive to be hospitable because it is their way of life. 
Armah employs syntactic parallelism to portray clearly European incursion and exploitation in Africa. Syntactic Parallelism according to Coghill and Magedanz (2005) is a rule of style stating that parts of a sentence that have the same grammatical function or weight should have the same grammatical form.

Isanusi had noted the danger of the presence of these white men in their midst in the following extract:

6. ... "These white men are not just pests. Isanusi said, They are dangerous animals, they are destroyers, they are killers” (p. 152)

TABLE IV: SYNTACTIC PARALLELISM OF THE NATURE OF EUROPEAN INVADERS

\begin{tabular}{ccc}
\hline \hline $\mathrm{S}$ & $\mathrm{P}$ & Compliment \\
\hline These white men & are & not just pets. \\
They & are & dangerous animals. \\
They & are & killers. \\
\hline \hline
\end{tabular}

For effective communication, Armah employs repeated expressions to underscore the intention of the white destroyers. The novelist further engages the structures of parallelism as a tool to powerfully demonstrate the cruelty, hypocrisy and ingratitude of the white destroyers. Portraying the pretense posture of the white destroyers, Armah states that they came first as traders "wanting to buy goods from us and sell us things" (p. 150). The way these destroyers are able to seduce some of the kings and courtiers, the like of king Koranche and flatterer Otumfor to support their wicked proposal is more disturbing, Armah utilizes pattern repetition to reveal the hypocrisy and oppression against Africans. He also exemplifies the intimidation Africans suffer in the hands of the imperialists, hence the several sentences of structural similarities with S P C structures displayed above conveys a sense of irony in the activities of the destroyers whose actual purpose was to turn the people into slaves. It is this oppression and slavery perpetuated by the destroyers that Isanusi and Abena fought against to liberate their people. The various noun phrases and verbs have syntagmatic relationship, that is, a relationship functioning horizontally. While all the verbs have paradigmatic relationship. The use of syntactic parallelism is to highlight the wickedness and hypocrisy of the white destroyers.

\section{Africans Enslaved, Tortured and Brutalized}

Armah's use of tenses beams light on how Africans have been marginalized and oppressed in their bid to liberate themselves from slavery.

David Crystal views tenses as a "category used in Grammatical description of verbs (along with Aspect and Mood), in referring primarily to the way the grammar marks the time at which the action denoted by the verb took place (p. 20). Traditionally, a distinction is made between past, present and future tense ( $p$. 479). As events in a novel are captured through various tenses, the significant tenses used by Armah are in the present, past, and future to communicate his message of Africa reciprocity and its aftermath. Examples are the followings:

7. It was the askaris' violent job to kill off all caught trying to end our oppression (p. 47).

8. Change, or we kill you, the first white predators, those from the desert, had said.

Believe in our road; abandon your way. Forget your ancestors; forget your posterity. Forget who your people are; forget your very selves and we will let your bodies live (p. 137).

Armah portrays how some Africans are responsible for fellow brothers' woes. These fellow brothers collaborate with strangers to keep their people enslaved and their women turned into playthings. The author made reference to the askaris and the zombis, who served as agents to the imperialists. "Women caught plotting their freedom had their bodies suspended and punished in an inhuman way" by the askaris (pp. 4748). The predators turned women into "playthings." This action challenged the women to revolt and to kill all the white destroyers. Rather than rejoice with the women for being able to defend themselves from the predators' inhuman treatment and slavery, the askaris at once began to assault them. It was the wailing of the women that brought everybody to the scene (p. 40).

Nandi, the grandmother of one of the askaris, was murdered by them. The askaris were no longer sensitive to the people's ways of life which they had determined to protect. Their insensibility led to the burning to ashes the relatives of all who spurned oppression (p. 71). Thus, their inhumanity is captured in the adjectives:

$$
+ \text { dangerous } \quad+\text { cunning } \quad+\text { poisonous }
$$

This loss of unity among Africans continues to slow down the pace for a rebirth, a movement towards renaissance. Besides, the various kings of the people did not help because they were all selfish and materialistic, especially king Koranche who adored the way of the destroyers and sent his son, Bentum to 
study their ways to the neglect of his peoples' way of life. Bentum's acquisition of foreign education influenced him to change his name to Bradford George. Consequently, he becomes alienated and detribalized, raised as a servant of the white destroyers and servant to Europe, where his African soul has been voided out of him. The king and his courtiers accept the destroyers' request to get people to work in the mines and on the plantations overseas. They, therefore, engage in persuading flatterer Otumfur to support their wicked demand (p. 157).

9. The king wishes you to know beforehand that as far as he himself is concerned - and that goes for his courtiers too - his heart responds kindly to all the white men's wishes, and he is of the mind to grant them (p. 127).

Armarh employs various moods to communicate how Africans were tortured, brutalized, and enslaved because of their principle of reciprocity. Revealing the various functions of speeches in the discourse, Armarh drew "a grammatical distinction in verb forms which express a speaker's attitude to what he is saying" (Hartmann \& Stork, 1972). There are three main moods. Indicative mood, imperative mood and subjunctive moods (Coghill et al., 2005). Armah utilizes these categories of mode in the followings. He employs indicative mood simply to declare that an action is so as in extract 9 above. An indicative verb can be in any person, number, or tense.

He also employs the use of imperative mood to state how these strangers came not ready to cooperate with the indigenes but to give orders, instructions, or commands as present in the abstract below:

10. Among the white destroyers there was no respect for anything we could say. They had comedetermined to see nothing, to listen to no one, bent solely on the satisfaction of their greed, of which we had ample news. But the king was infatuated with the white destroyers and would not heed the people's will, as quick in its expression as it was clear: to tell the white men to go (p. 66).

Armah also employs interrogative structures to highlight the suffering of Africans in the text. Richard Nordquist (2020) sees an interrogative as a type of sentence that asks a question, as opposed to statement, command, or exclamation. ... Interrogative is typically marked by inversion of the subject and predicate; that is, the verb phrase serves as operator before the subject (Nordquist, 2020). Importantly, an interrogative ends with a question mark. Armah deploys interrogative sentences to communicate his themes of African exploitation and slavery by the colonial masters. Armah relays how many Africans, the like of Isanusi and Abena, are determined not to compromise the principle of the way, which is reciprocity as evident in the extract below:

11. Faced with a people whose manifest purpose in life is to destroy life, we, people of the way, people of creation, where lies our fidelity? Must we remain upon the land we have come to call home, and there have the destroyers drag us each farther from the way that is our way? (p. 63).

12. "Slavery - do you know what that is? Ah, you will know it (p. 26).

\section{What new disease had added itself to his pains and ours? (p. 199)}

Extract 11 was the occasion when the people of the way realized that the strangers were determined to enslave them. Also at this time, many of the people of the way had been won over by Edusei and Abdullah who continuously worked on their minds and their bodies to accept the white predators' way of life. Thus, among the people, there was already a division created and "so were no longer of one heart" What can a people divided against itself achieve? (p. 60).

However, Africans are ready to abandon these predators whom they have given sustenance but have turned "vampires" to seek better place. Rather than be dragged "farther from the way that is our way". Thus, Africans continue to move away from a people whose principle is not in tandem with theirs. This is as expressed in the structure "Our way, the way, is not a random path. Our way begins from coherent understanding. It is a way that aims at preserving knowledge of who we are..." (p. 61). The interrogative is an indication of a zero tolerance for anything not African, the way of reciprocity. Although there were among them the zombis and the askaris, the servants of the imperialists who have been conditioned to do their master's bidding. The use of the modal verb "must" guarantees certainty that Africans' reciprocity can never be compromised. Consequently, they have continued to move to new land, towards a rebirth whenever this value is threatened. This attitude shows that Africans are peace loving people.

In extract 12, the author warns against a period when Africans will go into alliance with the destroyers (p. 28). He admonishes that Africans will be enslaved because they would have moved away from their principle of reciprocity, which is giving and receiving. Armah explains what slavery all is about. "He explains that it is about the destruction of the souls, the killing of bodies, the infusion of violence into every breath, every drop, every morsel of your sustaining air, your water, your food" (p. 27).

Armah sensitizes Africans of the horrifying experience and trauma of slavery, of the evil of slavery which was a major atrocity of colonialism as portrayed in "The slave driver pushed the burning iron against the captive's chest who yelled with pain" (p. 184). "The predators will consistently reduce these men first to 
beast then to things" (p. 46). The relatives of all who had spurned oppression were burned to ashes. Children not yet born burst out alive in that fire, then scalded with the hissing liquid of their mothers' wombs regained oblivion." (p. 71). Slaves will be "turned into things to be moved for use elsewhere, things bound for destruction (p. 189). Slaves will be whipped and treated in an inhuman way by the zombis and askaris (p. 198). All the above are highlights of what slavery is about.

Extract 13 is a recount of more examples of the sufferings of slavery, "their bodies and minds held down under the white destroyers' walls of wood and iron" (p. 202). The captives were packed like logs on ship. The place where they are kept are never cleaned. The zombis sent to clean the place did no cleaning, but rather came to "find entertainment whipping tied-down men." The place becomes very filthy that worms start to "eat the captives near the surface of their skins and killing them". This further compounds the suffering of the captive. Concerning the horrifying experience of slavery, Zahra (2008) notes how Ode Ogede has rightly argued that "by representing in his writing a sense of horrors, degradation, and humiliation of the experience of slavery, Armah participates in the process of racial reengineering of the black person. He admonishes every one of us to keep alive the memory of that most difficult of periods in black history, as the sense of the past... is essential to the future direction of society.

Armah utilizes exclamatory sentences to drive home the intimidation and abuse Africans were subjected in their bid to exercise their right. Rozakis (2003) notes exclamatory shows strong emotion. This is evident in the following abstract below:

14. "Watch!" one of the white destroyers answered him. "Let them stretch out their arms and also their legs, so!” (p. 171)

The setting in the above extract is in the white destroyers' ship. Here, Koranche the king tricked and sold a group of youth to the white destroyers as slaves. Earlier on, king Koranche had made a proposal to marry Idawa but, Idawa did not only return the king's presents of courtship but actually insulted him, calling him names. Therefore, this group of youth had problemes with the king. When the white predators requested for slaves to work for them overseas, Koranche tricked these youths and pretended that he had forgiven them. Therefore, when the youths received the report that the king's anger had cooled, and that the wisdom of the ancestors had entered his head, and had decided there was no reason for resentment against Abena or against any of them. The youths were happy and decided to honour the king's invitation to a feast, p.165. Isanusi had earlier on warned Abena and the group against the danger that awaits them there because he could sense evil in the invitation and in plain language, he said to them, "if you knew who you were, you would accept no invitation from black men who call white people friends". He noted that such unwanted friendships were fed by bloody interest, and cautions them against falling prey, p.166. Every counsel of Isanusi fell on deaf ears. True to Isanusi warning, the youth were enslaved and chained together at the feast with special bangles and anklets.

A dramatic irony plays out here as the captured youths are ignorant of the white destroyers' ploy to enslave them by chaining them together. Koranche mocks the youths when he saw that they have been chained together. As reiteration for all the youths' insubordination to him, he abandons them in the ship which will take them away as slaves. The irony is that the youths did not understand that they have been trapped but were busy admiring the bracelets and bangles won them. Meanwhile, the king and his courtiers had mocked them and betrayed them and abandoned them in the ships (p. 171).

It was in the process of trying to remove the ornament that the youth finally discovered that they have been enslaved. The first exclamatory word "watch" calls for the king's attention to see how the wrist and ornament of the anklets would size them very well. While the consequence of the second exclamation "so" is elipted because the white destroyers want the youths to be ignorant of what they were doing. Thus, Koranche, the leader of the people of the way is seen not to be working in tandem with the philosophy and mandate of the people of the way. He sells his subjects into slavery. This is man's inhumanity to man.

This attitude is replicated in several African nations where leaders are after how to enrich themselves. Such selfish leaders should be voted out and dynamic and patriotic ones elected to help move the identity of Africa people forward.

\section{Reprisal by Africans}

Armah notes how Africans at various setting fought to gain freedom from the predators whom they had given sustenance but turned against them and enslaved them. Examples are the followings:

15. How many died quieter death that night with daggers stuck into their throats? How many tried to vomit poison, and found it had already tied their stomachs and the sinews of their throats rigid with action? (pp. 38-39).

16. Women leapt headlong from the ship, men leapt into the seawater from the side away from the destroyers' corpses in joy of liberation ... (p. 223). 
17. Too late. We destroyed the destroyers there before the gate. When afterwards we went to their ship we found the captives on it near death. ...The ship was small; where we found the captives there was no breathing space. After healing, all the survivors wanted to return back home. (pp. 262-263).

In extract 15, the women whom the predators from the desert turned into "plaything", fought vigorously to free themselves from been used as such. The women revolted and killed the destroyers. To portray how many at times, Africans are enemies of themselves, the askaris who are Africans working for the predators, descended on the women and began to assault them and to kill them instead of them to rejoice with the women for being able to defend themselves from the predators' inhuman treatment and slavery, It was the wailing of the women that brought everybody to the scene. (p. 40).

The use of the repeated WH- words in:

How many died quieter death ...

How many tried to vomit poison...

highlights the number of the predators killed by the women. The use of syntactic parallelisms emphasizes the number of the predators killed by the assaulted women. The use also informs the readers that although Africans are a people of reciprocity, they can also fight back when the opportunity arises and therefore should not be taken for granted.

In extract 16, we find how providence was on the side of the captured Africans. As they were being taken away in ship to Europe as slave, there arose a strong storm that cause the ship to begin to sink. As they were moved in boats as goods for safety, the slaves took advantage of the situation and fought vigorously, overpowered, defeated and killed all the white destroyers. In jubilation, they celebrate their victory over the predators. After they gained freedom, the freed captives returned to their home to start a new life. Armah utilizes the past tense structure to relate the importance of freedom. As a liberated person, you decide what you like to do without coercion.

The setting of extract 17 was in the predators' ship back home in Africa which was ready to take slaves away. When the freed captives returned home after killing all the white predators on board the ship that sank, they came back to meet that the white predators had consolidated and had built themselves a stone place and that they continued in their act of capturing Africans who are deported to Europe to work in the plantation, With the help of Kamuzu, a chief , Isanusi and others, were able to kill all the white predators on board the ship and they released the captives whom they found "near death, most of them." because the ship was small.

After healing, all the survivors returned back home (pp. 262-263).

\section{CONCLUSION}

This paper reflects African manner of assertion towards the trajectory of renaissance right from the invasion of the destroyers from across the desert and across the sea respectively. Though these destroyer have tried to destroy Africans and enslave them, Africans will continued to be hopeful and certain of how they would bounce back again and all that will be remembered will be history.

This hope is premised on the fact that various voices being raised across the continent are unrelenting and in tandem with a return to our way, the African way of life. Therefore, Africans should continue to raise their voices until they are heard. This they could do by electing political aspirants who visionary, selfless and credible. Such leaders will be able to secure the various countries in the African Union (A U) and also be able to provide the dividends of democracy to the people. For instance, in Nigeria, the generality of the populace is disaffected and disappointed in the selfish Fulani agenda which has caused much pains in terms of destruction of lives and property in the country. Thus, the hope for a positive change is being rekindled to ensure a truly detribalised, patriotic Nigerians are elected to political offices come 2023 general election in the country. The spirit of renaissance and hope is sweeping across the continent of Africa as a result of education, enlightenment and conscious commitment about how to transform the society for the good of all.

\section{REFERENCES}

Abrams, M.H. \& Harpham, G. (2005). A glossary of literary terms. Boston: Thomson Wadsworth.

Armah, A. K. (1979). Two thousand seasons. Chicago: Third World Press.

Armah, A. K. (1979). Two thousand seasons. Heinemann.

Chester H. Jr.www.africanholocaust.net

Coghill, J. \& Magendanz, S. (2005). Cliffstudysolver eng lish grammar. Hoboken NJ: Wiley Publishing Inc.

Crystal, D. (2008). A dictionary of linguistic and phonetics (Sixth Edition Maldem). U.S.A: Blackwell Publishing.

Edoki, J. (2008). The Upward Path. Yaba, Lagos: Nopkia Ventures Limited.

Eggenschwiler, J. \& Biggs, E. D. (2001). CliffsQuickReview writing: grammar, usage and style. New York: Wiley Publishing Inc.

Eze B.U. (2008) A Brief Outline on the Geographical Background of Africa. In: Holbrook J.C., Urama J.O., Medupe R.T. (eds)

African Cultural Astronomy. Astrophysics and Space Science Proceedings (pp. 29-38). Springer, Dordrecht.

https://doi.org/10.1007/978-1-4020-6639-9_3 
Hartmann, R.R.K. \& Stork, F.C. (1972). Dictionary of language and linguistics. London: Applied Science Published LTD.

LinguapressEnglish Grammar. "The Word "So" in English." linguapress.com

Nordquist, R. (2020). InterrogativeLinguap.comress. Sentences: Glossary of grammatical and rhetorical terms. https: www.thoughtco.com Updated Feb 05, 2020.

Nwahunanya, C. (2007). Literary criticism, critical theory and postcolonial african literature. New Owerri: Springfield Publishers Ltd.

Oyedele, O. (2020, February 24) "Important Security Admonition: Remember Hudaybiyyah" in Voice of O'Odua.

Https://www.facebook.com/permalink.php?

Rozakis, L. E. (2003). The complete idiot's guide to grammar and style. Second Edition. New York: Penguin

Szalay, J. (2016). "The renaissance: 'the rebirth' of science \& culture” in Livescience www.livescience.com

von Clausewitz, C. (2012). On War. CreateSpace Independent Publishing Platform.

Yankson, K. (1987). An introduction to literary stylistics. Obasi: Pacific Publications.

Zahra, M. B. (2008). Why "the order" in Two Thousand Season? In open edition books, P,311-322.

Zondervan (1999). Comparative Study Bible: New International Version, Amplified Version, King James Version. Updated New America Standard Bible, Revised Edition. Michigan.

Dr. Mrs. Grace Iyengumena Omo-Ojugo was born in Owo, Ondo State, South-western Nigeria in 1958. She attended Institute of Continue Education, Benin City where she obtained her WASC (West African School Certificate) in 1974. Thereafter, she proceeded to College of Education Abraka in Delta State where she obtained her NCE (National Certificate of Education) degree certificate in 1977. Thereafter, she proceeded to Delta State University where she obtained her B. A. (ed) English in 1995. After teaching for some years, she proceeded for her Masters and Ph.D in English in Ambrose Alli University, Ekpoma, Edo State in 2002 and 2007 respectively. She earned the Master and Ph.D certificates in 2006 and 2012 respectively.

She lectures in Ambrose Alli University, Ekpoma - Edo State, Nigeria. She is a Senior Lecturer in the Department of English. She joined the services of Ambrose Alli University, Ekpoma as an Assistant Lecturer in December, 2006. She obtained her Doctoral degree in English in 2012 specializing in discourse analysis. Her last three publications are:

Grace Iyengumena Omo-Ojugo \& Justina Ngozi Edokpayi (2019). A Lexico Semantic Anlysis of Tanure Ojaide's "Waiting for the Hatching of a Cockerel in Multidiciplinary Journal of Arts and Language Education (MJALE) VOL. 2 No 1, 2019 (Ekiti, Ekiti State: Ekiti State University, Ado-Ekiti, 2019).

Omo-Ojugo, Grace I. \& Okugbe, Monday A. (2020). "Language and Creativity for Sustainable Development" in Journal of International Association of Language Educators (JIALE). Special Edition, 2020 (Ile-Ife, Osun State: Obafemi Awolowo University, Ile-Ife, 2020)

Grace I. Omo-Ojugo and Justina N. Edokpayi (2021). "A Discourse Analysis of Some Visionary Poems of Anti- colonialism by Leopold Senghor and David Diop" in LANGUAGE MATTERS IN CONTEMPORARY WEST AFRICA: A REFEREED BOOK IN HONOUR OF PROFESSOR FRED I. EMORDI. (Porto-Novo, Républiqué du Bénin: Editions Africatex Média 2021). She is currently working on TOWARDS AFRICAN RENAISSANCE: A LINGUISTIC STUDY OF AYI KWEI ARMAH'S TWO THOUSAND SEASONS.

Dr. Omo-Ojugo, is a member of the International Association of Language Educators (JIALE). She is presently involved in the planning for 2022 Faculty of Arts International Conference. 